\title{
REGENERATING THE SPATIAL PATTERNS OF CONTEMPORARY NEIGHBORHOODS IN TEHRAN BASED ON TRADITIONAL NEIGHBORHOOD PATTERNS BY EXAMINING THE EVOLUTION OF TWO PERIODS OF QAJAR AND CONTEMPORARY
}

\author{
Nasibe Barati Goudarzi \\ Faculty of Architecture and Urbanism, Tehran University of Art, Tehran, Iran \\ nasibe.barati@gmail.com \\ Fariba Gharai \\ Faculty of Architecture and Urbanism, Tehran University of Art, Tehran, Iran
}

\begin{abstract}
Passing from traditional society to modern and from modern to network society is emerging whole world by leaving bad and good effects. Iran has passed this transition from traditional to modern very quickely without preparing scientific, cultural and artistic bases. Old neighborhoods which were places to ghatering people with common Ethnic, religious, social and economic properties gradually had been distincted from environs during the lapse of ages. In this Study patterns and origins of traditional neighborhoods of Tehran city and revolution of transformation have been studied and analyzed by reconsideration theories and aspects. For needed information in this case of study two neighborhoods from different periods have been selected. Odlajan from Qajar age and Shahid Bagheri in 22 zone of Tehran from contemporary. Evaluation of the resulting patterns based on theorical foundations and studies has caused regenerating these patterns to employ in contemporary neighborhoods designs. Based on the principles and patterns extracted in the theoretical foundations of traditional neighborhoods and the needs of today's society and recreating the patterns and principles, principles and standards proposed in the form of three factors of form (the form of physical, urban perspective), performance (system of land use and activity, movement and access systems), perception (skeletal public space) have been suggested.
\end{abstract}

Keywords: Traditional neighborhoods, Contemporary neighborhoods, Regenerating traditional patterns, Spatial patterns 


\section{TAHRAN'DA ÇAĞDAŞ MAHALLE KOMŞULUKLARINDA MEKANSAL DESENLER VE KAÇAR'IN İKI DÖNEMINDE GELENEKSEL MAHALLE KALIPLARININ GELIŞ̧iMI}

\section{ÖZ}

Gelenekselden moderne geçiş sürecinde toplumlar üzerinde olumlu ve olumsuz etkiler olmaktadır. İran toplumu da gerekli bilimsel, kültürel ve sanatsal altyapı oluşturmadan modern topluma geçiş sürecini çok hızlı yaşadı. Etnik, dini, sosyal, ekonomik, vb ortak özelliklere sahip insanlar için toplama yeri olan eski mahalle zaman geçtikçe yavaş yavaş belli bir kimlik oluşturdu. Öte yandan, mahalle kimliği ve fonksiyonel mekan işlevi etkili olmuş ve özellikle yaşam tarzı da ortak amaçlar ve mahalle sakinleri, (purjafar) çıkarları yaratılmasına yol açarmıştır. Bu gelişmeler mahalle çerçevesine yansıyan ve aynı zamanda mahalle sakinlerinin tüm ilişkilerinde anlam ve hayal, sosyal, kültürel, ekonomik ve kamu gibi etkenler dönüşüm yaşamıştır. Bugünün mahalleleri onların kurucu unsurları ve yapısı (mahalle merkezleri, ağ erişim, meydanlar, konut, mahalle tesisleri) ve hiçbir sakinleri geleneksel çerçevesinde diğer mahalleler ile iletişim için önceki performans değil böyle bir şekilde dönüştürülmüştür. Tahran'ın tarihsel yapısı mekansal anlamda bir hazine gibidir. Tahran şehri, teknikleri tasarlama yöntemlerini anlamak için yardımcı olmakta ve aynı zamanda geleneksel yerli kültürüne dayanan Tahran'ın çağdaş mahallelerde yenilenmesi için alanlar sunabilmektedir. Bu çalışmada, Kaçar ve Pehlevi dönemleri Tahran şehrinin geleneksel kentsel tasarım ve çıkarılan çağdaş mekansal desen ve ilkeleriyle sunulmaktadır. Bu araştırmada nitel yaklaşımlar doğrultusunda saha gözlemleri, anketler yapılacaktır. Örneklem olarak seçilen Pehlevi döneminin Odlajan mahallesi, Kaçar ve seçilen NARMAK 22 bölgesinin çağdaş dönemine ait etkili desenleri çalışmada analiz edilecektir.

Anahtar kelimeler: geleneksel desenler, geleneksel mimarisi, Çă̆daş yapı yeniden canlandırmak, Uzay yaptst

\section{INTRODUCTION}

The emergence of concepts such as collective living quarters and how they have their roots in social behavior is derived from the particular culture of that time and place. Tehran metropolitan past four decades which owes much of its texture, not only was a cause of making the national level identity, but lost the few characters left over from the past. today's Tehran is a mix of spatial contradictions and tissue aging process of modernization and high rises of downtown and north districts of the newly established areas are obvious from this fact. Tehran neighborhoods are not the same in terms of area and population covered and the formation of communities is the function of factors such as the time of emergence of neighborhoods, the position of aqueducts, social structure and the tribal communities living in those villages in extension and prime land, especially the famous gardens and large landholdings.

Tahsildar and Habibi began their studies on the structure of the traditional places of Qajar era.

Tahsildar and colleagues in 1372 [1] concluded from studies that in Qajar era the neighborhood growth was done through the old quarters and new neighborhoods was a function of previous neighborhoods. Habibi studies [2] in the structure of the traditional places of Qajar period shows that during this period "the main hinge backbone of the city is still the market. Rahnamayi and Shah Hussein [3] investigated the factors influencing the structure of their neighborhoods during the Qajar period. Legal instruments to implement structural changes in the city legislation such as the law of municipality (1309), widening of roads and development (1312), were provided. 
In a study in 1389 Shamaei [4] on the Yazd made clear that the uncontrolled growth of Yazd causes challenges between traditional and modern urbanism. Shamaei announced that the current structural problem neighborhoods are uneven and unbalanced development of urban and break the spatial organization of the city abandoned land in the territory of city, lack of balance and density per capita of urban poor, non-compliance and compatibility with the geographical situation, lack of the security and safety neighborhood of the city, increasing the cost of transportation and unaffordable facilities and infrastructure in some parts of the city.

Present research is qualitative research which using the descriptive-analytical method and pragmatic methods applied to study of theories and perspectives to analyze the evolution of the traditional neighborhoods of Tehran at Qatar, Pahlavi and contemporary periods.

\section{THE CONCEPT OF RENEWAL}

Urban regeneration is the process of creation which leads to new urban spaces while preserving the original features of spatial (physical and activity). In this study new urban spaces occur, exhibit fundamental similarities with the old urban areas, substantive and semantic differences with the old spaces. Urban renewal in many developed countries implemented in response to problems associated with wear and urban pest, introduced as an intervention method. The concept of urban regeneration, depending on the level of development of each country, interpreted and used in different ways [7].

\section{THE CONCEPT OF NEIGHBORHOOD}

The concept of neighborhood means in addition to the physical is tied to social and cultural structures of societies can be said it takes specific definition in each country. For example, in Morocco neighborhood has less commercial office concept rather than symbolic concept. What is known as neighborhoods in traditional design of urban areas of Iran includes physical, cultural and social characteristics and is quite different with the concept of neighborhood in the West.

A set of principles and models for the structure of neighborhoods is needed that is mentioned scattered in that areas. Based on this investigation of concept of the spatial structure and its conceptual model, a model proposed for the spatial structure of the neighborhoods which is considered in this study, to facilitate the analysis and evaluation in this format of traditional and contemporary neighborhoods.
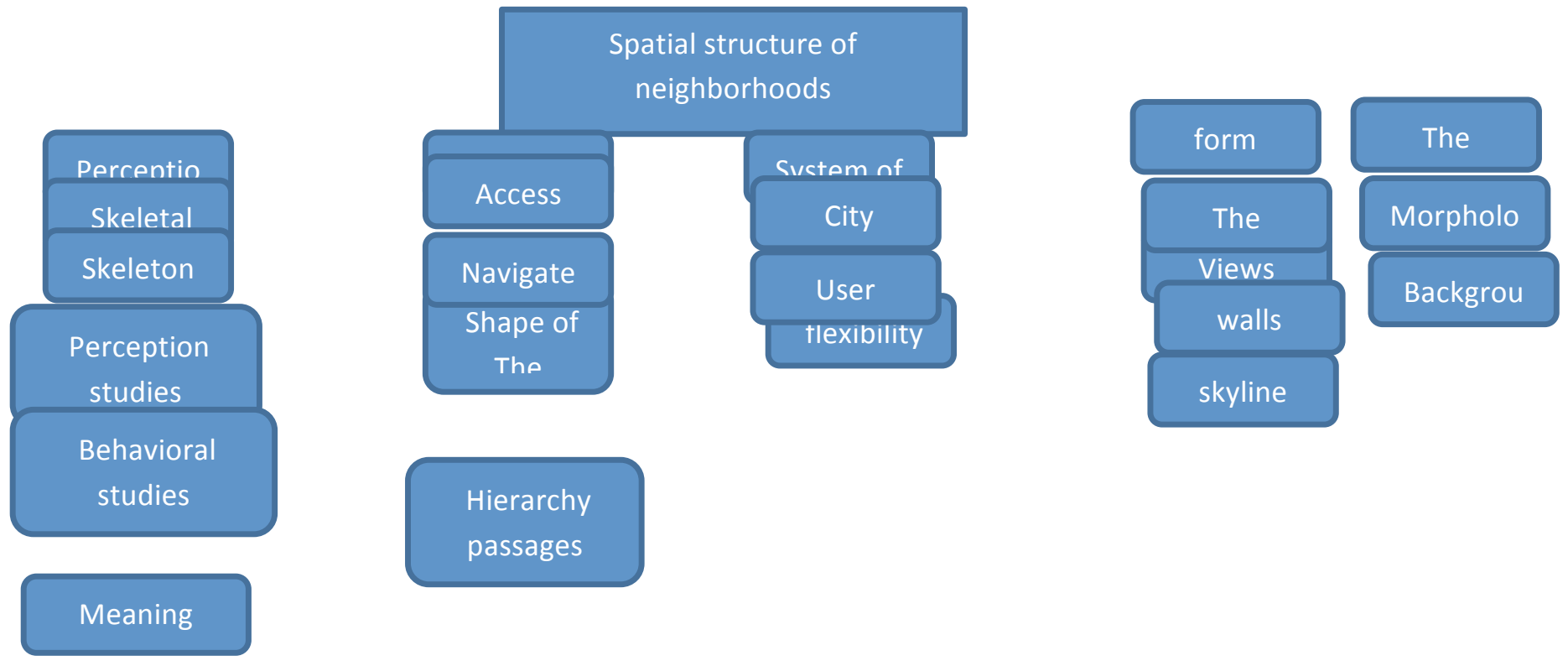

Figure 4: harmonious relationship glazed elements and components of Views 
Tehran metropolis from a small village to the national development process, the following steps have been taken:

The first phase of the village of Tehran: Tehran was a village outside the ancient city Rey, Tehran, one of the trivial villages of great city and great center of ancient Iranian civilization and culture of Rey which was placed approximately six kilometers far from [8].

Tehran Shah Tahmasp period: Tehran in the second half of the tenth century AD was the focus of Shah Tahmasb. He ordered new buildings in Tehran and caravanserais and strong build towers and walls In fact, the first official buildings of Tehran had to be built during the period of this king.

Tehran, the capital of Aqamohamadkhan: This year was the beginning of a new chapter in Tehran progress (Khalili Araghi; 2: 1367). Four residential neighborhoods include: Sanglaj, Odlajan, Bazar and Chal meydan. In the beginning of the capital of Tehran by Agha Mohammad Khan, on the basis of political and military considerations, the city became an important center of political, military and administrative center and commercial and consumer market emerged in its focus.

Tehran of Naseri period: In this age should be referred to the preparation of the map of Tehran. The first map as the map of the capital Tehran provided by the French Mosio Kershish in the seventh year of the reign of the Naseraddin Shah where the city's main elements are: Citadel with a fence around them, mosques, schools, markets, squares and neighborhoods that feature of the Isfihan is evident.

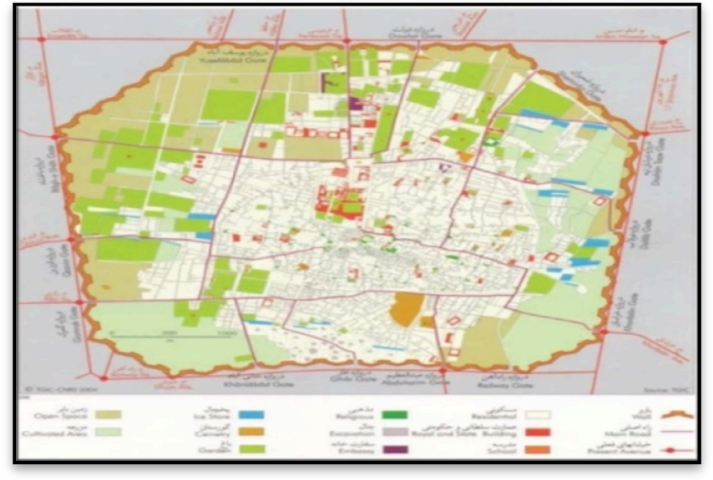

Fig3. Tehran map in 1269, Abdolghafar map

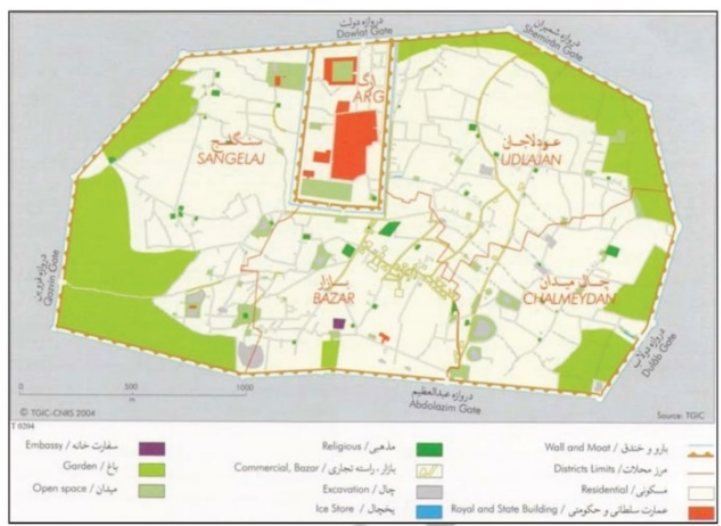

Fig2. Tehran map in 1220, Brezin map

\section{THE TRADITIONAL STRUCTURE OF NEIGHBORHOODS:}

The inner part of the historical cities of Iran has a special structure which is the result of geographical and climatic factors, socio-cultural, economic and population base in the city administration, socio-economic status of the residents of each neighborhood, building materials and techniques which formed over the centuries. The following features of the spatial structure of neighborhoods in the form of three factors form (the form of physical, urban perspective), performance (system of land use and activity, movement and access systems), perception (skeletal public space) that has been in general as follows: 2-2-1 system in physical form

\section{MORPHOLOGY}


In traditional Iranian cities and neighborhoods in the city's entrance gate was used inside the fence and gates that were in the cities, the inner gate were considered. These gates can at least be divided into three groups: the gates of the government, the market gate, the gates of the neighborhood.

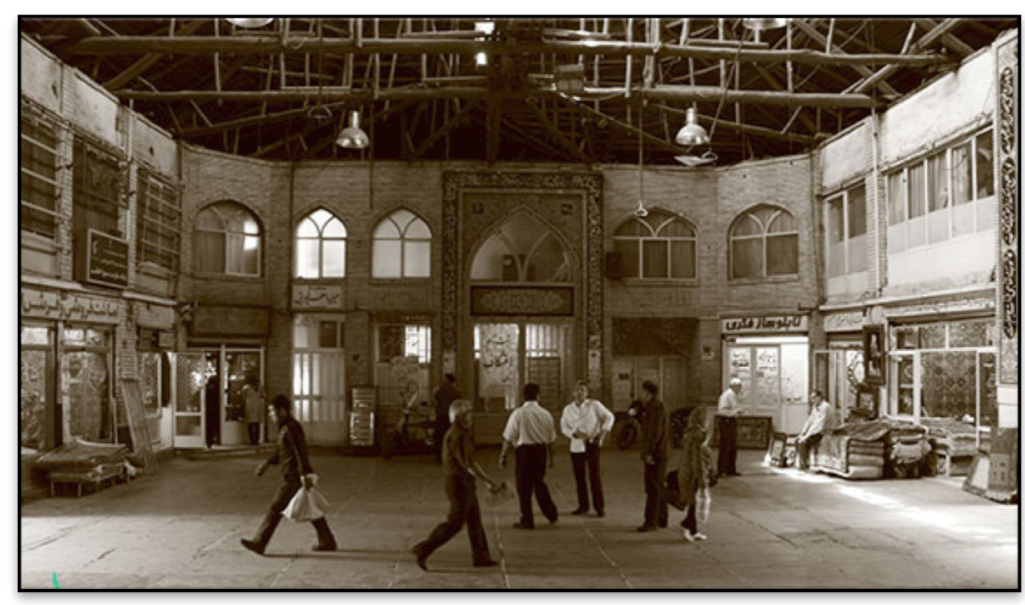

Fig 4. ..... indoor in Tajrish

The next thing about the traditional neighborhoods, is orientation towards space in traditional Iranian cities towards Mecca which one of them is an important and positive social feedback that is one of the aspects of reinforce unity worship of the social cohesion and underlying strong relations between the inhabitants of the cities.

\section{BACKGROUND}

In traditional cities every ways also have any of the characteristics of the position and were almost certain that it was so direct and control the current behavior and also there were enough readable.

In traditional neighborhoods which now forgotten, we can distinguish and separate three-phase, with different characteristics from each other:

1) Private outdoor courtyard and it comprises the elements.

2) A semi-private or semi-public for a private dead end or porch which contain road to a few houses.

3) Public space for the passage of the field. [12]

\section{THE URBAN LANDSCAPE}

\section{VIEWS}

The ancient cities of Iran has a wealth of contrasting spaces and is different from the human scale. The value of contrasting spaces is that they reduce the monotony of connector spaces. Broad and narrow and enclosed space as well as we can see them in warm and dry cities also created contrast in space . 


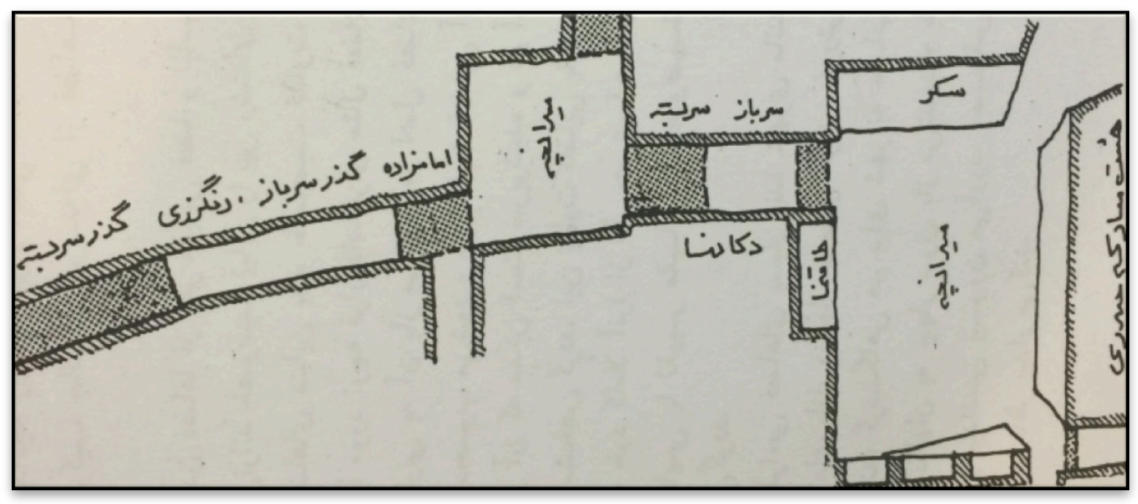

Figure 5: contrasting spaces created on track with indoor and outdoor passages] 13[

\section{CHAMBER}

Residential units which contained openness and open space in the entrance to the house, native home residents or visitors could rest on it or to talk to their clients.

\section{SKYLINE}

Local internal face of neighborhoods coordinated supply perspective and a little number of houses, which at the height differentiates itself from the other houses. Often buildings had one-story and some two stories high and only some buildings such as mosques, schools and palaces were of greater height [14].

\section{SYSTEM OF LAND USE AND ACTIVITIES}

In great neighborhood, great monuments and public collections, were constructed along the main road of the neighborhood in addition to the center of neighborhood. In these neighborhoods, in addition to the necessary facilities for citizens, cultural and religious buildings such as schools and monasteries were built. In the neighborhoods that were near commercial centers, one or more of the production workshops and inns, were made where not bothering residents [15].

Bazaar: Some great neighborhoods in major cities have their own marketplaces. The little markets were squares or just passing places.

Mosque: there was central Mosque in the city as a symbol of the city. In small cities which contain lower and limit neighborhoods there was only one mosque as a central mosque.

Bathroom (bath): bathrooms gained a lot of importance after Islam and were excluded from the aristocracy. Typically baths were built next to important buildings such as mosques and important houses. Water storage: another components of the central neighborhoods o, is water storage. Especially in cities such as Nain, Kashan, Yazd which access to drinking water simply was not possible for all people.

Commercial shops: Aside from the neighborhood market, within the fabric of the neighborhood and its subsidiary also in other passages of necessity, some commercial shops such as grocery, butcher, bakery and ... were created for the residents of the neighborhood.

School: One of the places where had most urban function, but in large communities, sometimes is formed within the tissue.

\section{MOVE AND ACCESS SYSTEM}

In terms of communication networks in traditional of urban planning, roads contained hierarchical order and not just the role of communication. Their role in relation to the natural and environmental factors, such as sunlight, wind flow and obvious signs of a city with buildings, cultural and social characteristics 
and needs of communities and neighborhoods. By above study, the abstract of spatial structure of traditional neighborhoods and the reasons for their use are given in the following table:

Table 1: Spatial structure of traditional neighborhoods and the reasons for their use

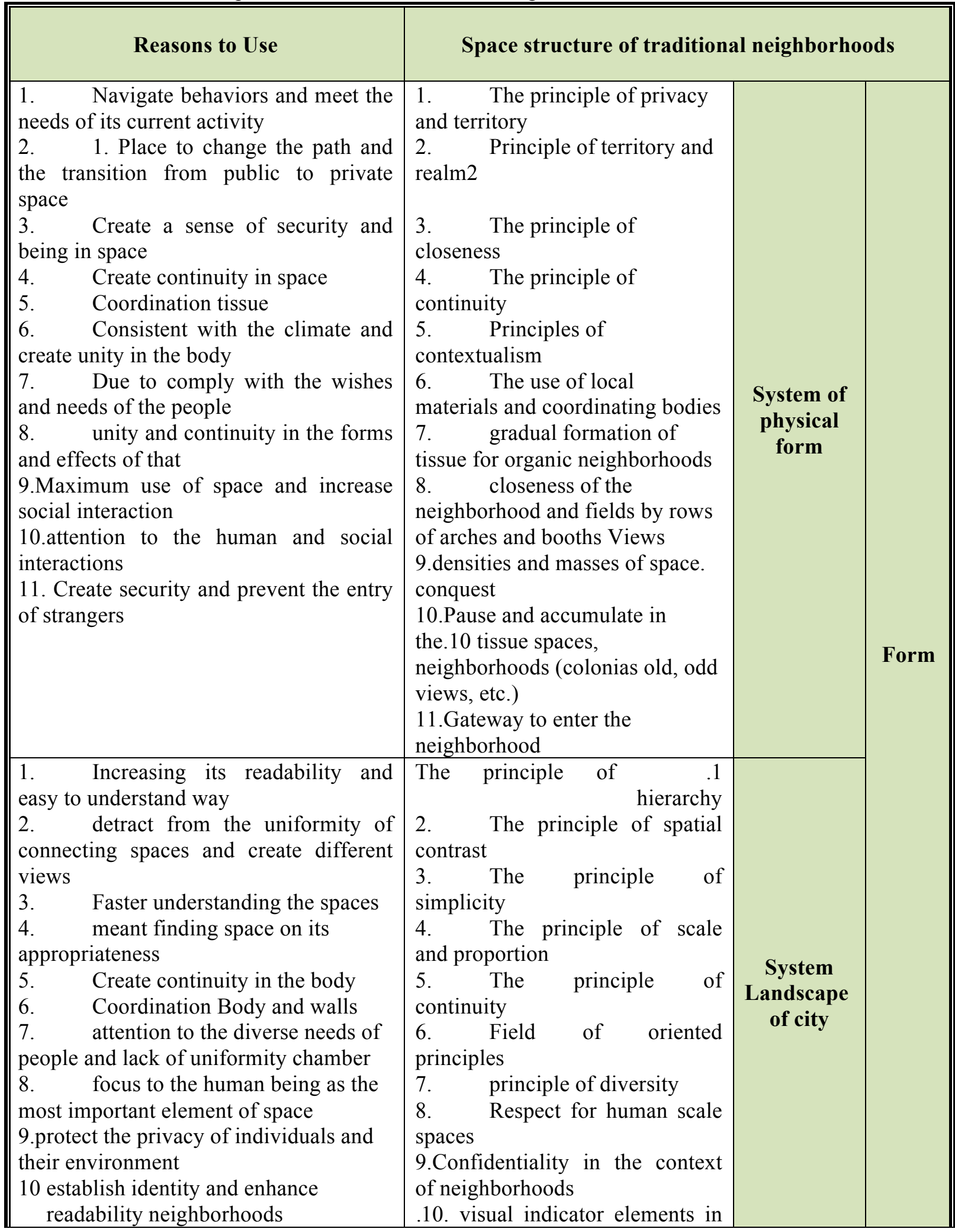




\begin{tabular}{|c|c|}
\hline $\begin{array}{l}\text { 11. As a sign of the difference in height } \\
\text { 12.Coordinated tissue Because of height } \\
\text { and taller height indication elements }\end{array}$ & $\begin{array}{l}\text { the neighborhood } \\
\text { 11.skylineCoordinatedand } \\
\text { uniform Aside from the elements } \\
\text { as signs } \\
\text { 12.Urban Horizon convex }\end{array}$ \\
\hline
\end{tabular}

\section{IDENTIFICATION AND ANALYSIS}

In this chapter a sample case was selected from each period to reach an appropriate spatial structure of traditional neighborhoods and recreating them according to the today needs which is need to consider three period and reach neighborhoods changes have necessitated. The neighborhood Odlajan from the traditional period and the period after the revolution, Shahid Bagheri town has been selected.

\section{ODLAJAN}

\section{UNDERSTANDING GROUPS}

The first master plan which is the most important experience in preparing comprehensive plans in Iran, Tehran as a metropolitan area is assumed to be abstracted from its surroundings and the smallest study about the crowd around it didn't made. This plan was the starting point to intensify these effects and problems caused by it because of the nature and diversity of nature in the city, and physical-spatial and socio-economic of the system. In the third master plan, despite the crisis out of range, the uncontrolled growth of the population and the surrounding towns and populated places in space shielding, Tehran has been studied in abstract terms again.

A positive point which can be seen in the third master plan, especially notice of this plan to the structure of historic within the old city of Tehran and guide the internal developments and changes of Tehran which is derived of cultural needs, social and economics of the city.

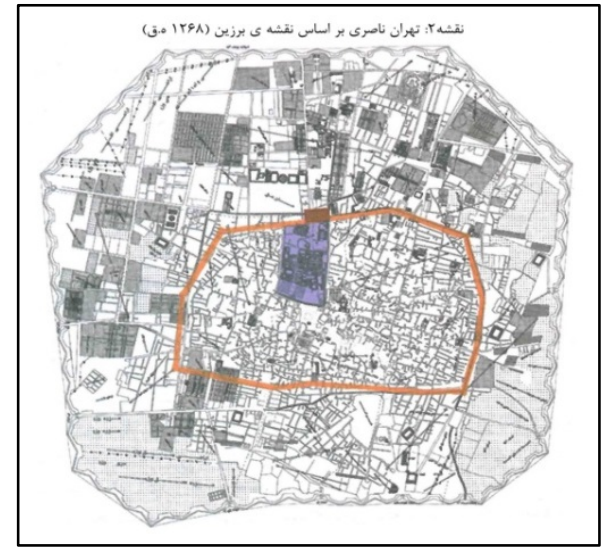

- The destruction of the first fertility and growth of the city to the north (the formation of neighborhood Odlajan)

- $\quad$ Create the first urban streets in the northsouth stretches the fertile Safavid and strengthen harmonization by strengthening urban elements of the government's reaction in the neighborhood - Destruction Netting importance of reproductive organ and field artillery and the

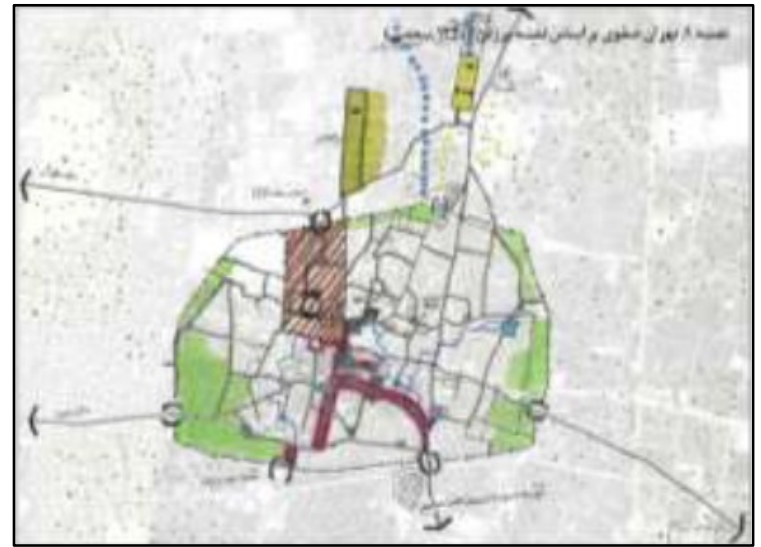

The formation of fertile places of origin within the Safavie and development of marginal lands, mostly in North
- $\quad$ - The loss of fields and farms in the northern neighborhood of Odlajan and the main stretches of tissue formation Construction of gardens and royal palace outside the fort and the importance of north-south tracks weave in the northern part of the city 
streets of Naserie

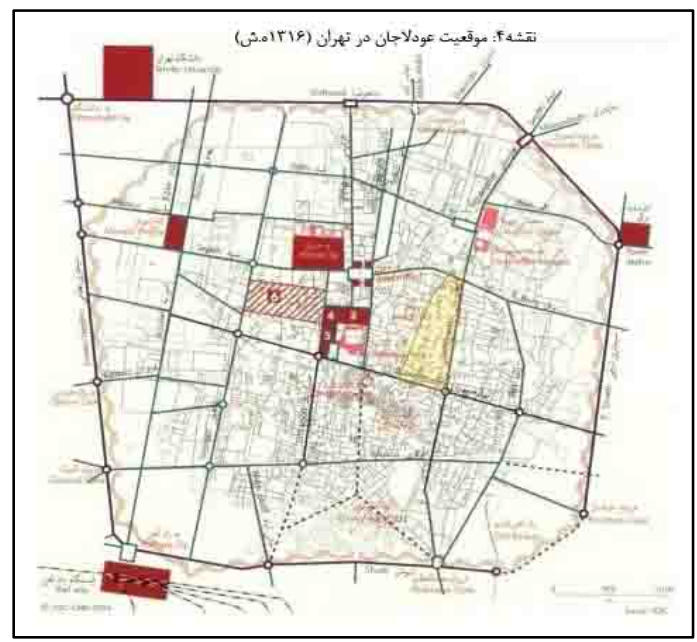

Create the main streets in the neighborhood Odlajan

- $\quad$ The formation of neighborhood with its modern form and divide the neighborhood into three distinct sections

The formation of the city's most important elements in the surrounding neighborhood and the importance of weaving the market Odlajan

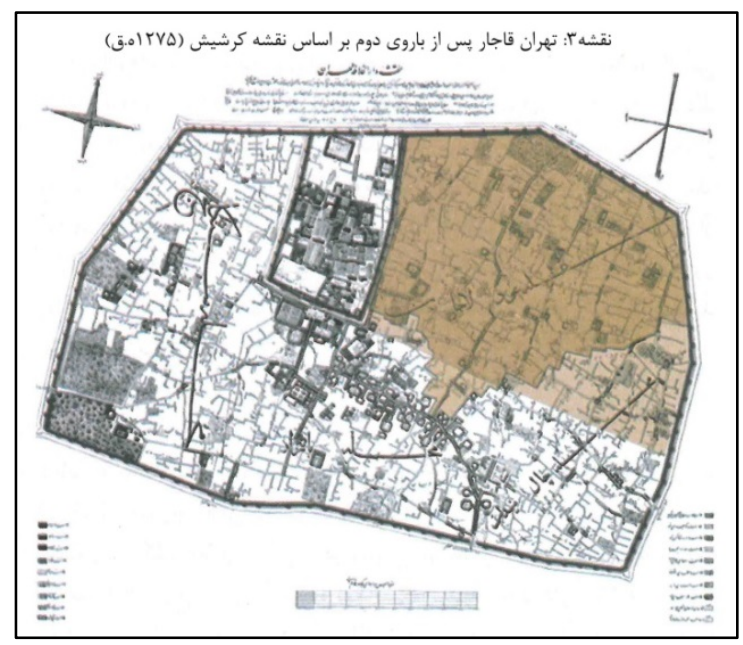

Complete city inside the walls of the Safavids and the final completion of the five neighborhoods

Create the ultimate form Odlajan and the formation of split core elements and community context

- $\quad$ Building service activities and urban collections in the ghetto, and the finalization of the boundaries of the neighborhoods Odlajan

Figure 6: Comparison of Tehran and neighborhood map Odlajan in different historical periods

In tehran map of 1275 Tehran divided to five original quarters,Arg, Odlajan, chale meydan, and Sanglaj. In 1309 map Dolat neighborhood, added to the previous five parts.
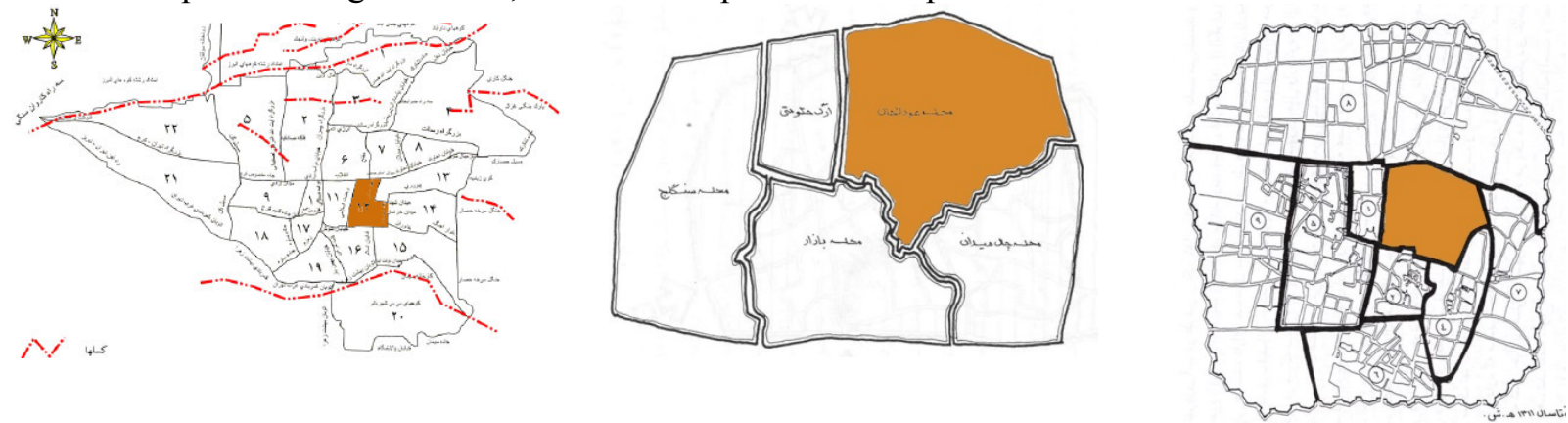

Figure 7: Position neighborhood Odlajan between historic neighborhoods and 22 districts of Tehran (Source: BAVAND Consulting Engineers)

\section{- ODLAJAN TERRITORY}


From the north: until 1284 limited to the north fence and then limited to Cheragh Gaz street . From East: until 1284 limited to Eastern Fences and later confined to the Kamranye (Ray) street. From the South: limited to the Chale meydan and bazaar. From the West: until 1282 is limited to the Citadel fence and later confined to the streets of Naserie. Now the west neighborhood: Naser Khosrow Street, from the north Amir Kabir Street, from the East Rey Street and its south 15 Khordad street
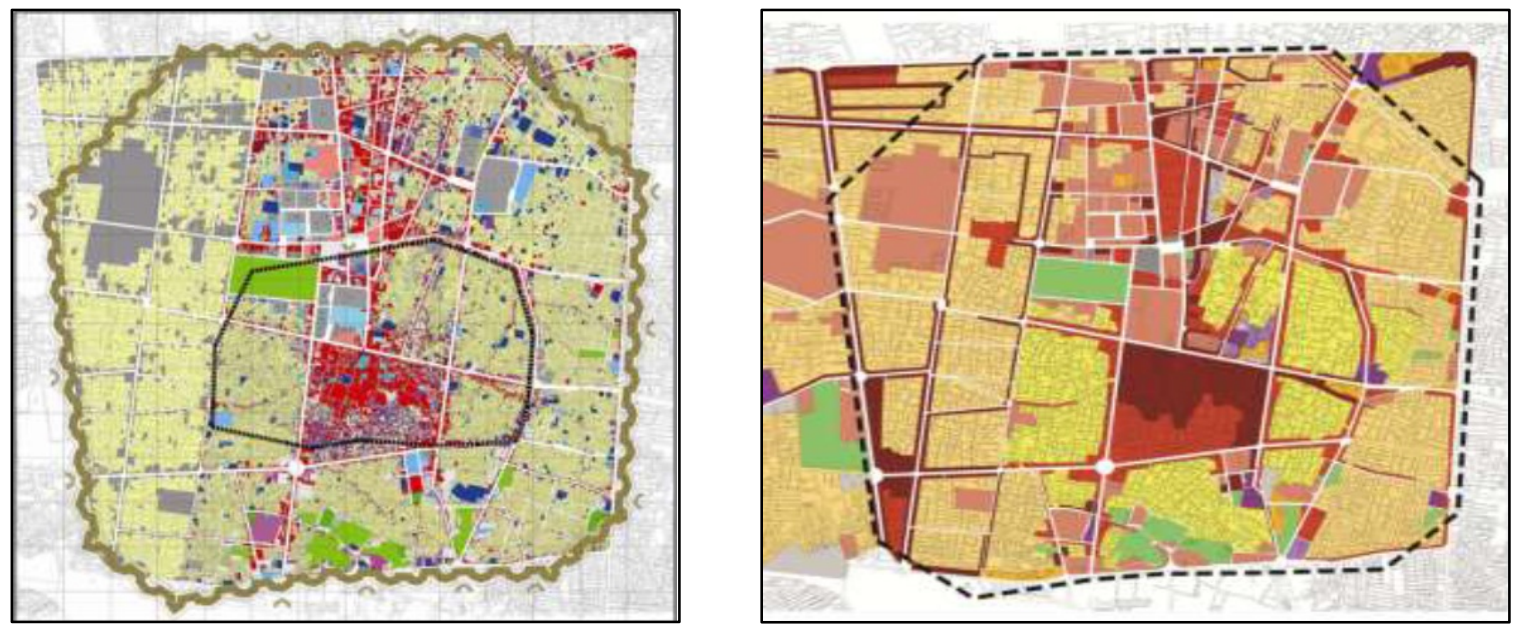

Figure 8: Odlajan in the historical area of Tehran, land use (source: Consulting Engineers BAVAN)

\section{RECOGNITION AND ANALYSIS OF THE STUDY AREA}

\section{THE PHYSICAL FORM}

The physical form of the neighborhood is shown in figures ( 9 and 10). Apart from the construction of new tissue within four to five floors, most buildings in the tissue and in the neighborhood during the transition are one or two floors. This is caused due to physical scale, coordinated entity Arises during the transition and neighborhoods.

The skyline is also experiencing disharmony, also transition and spaces contain of sufficient closeness.

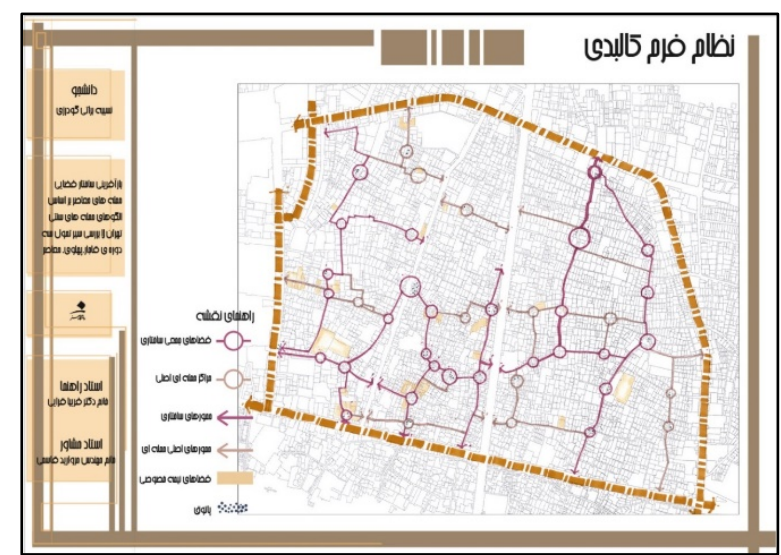

Figure 10: The principle of privacy and space in the hierarchy territory neighborhood Odlajan (Source: author)

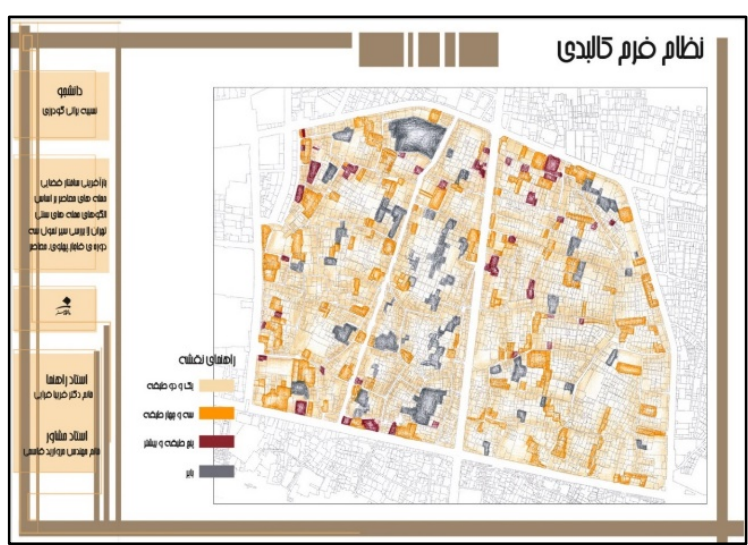

Figure 9: Structural classes Odlajan (Source: autho)

THE URBAN LANDSCAPE 
In terms of features seen in the neighborhood, tracks of neighborhood are close, this closeness of main and secondary routes and many twists and turns along the way, also new construction, has led the views of the neighborhood are closed.
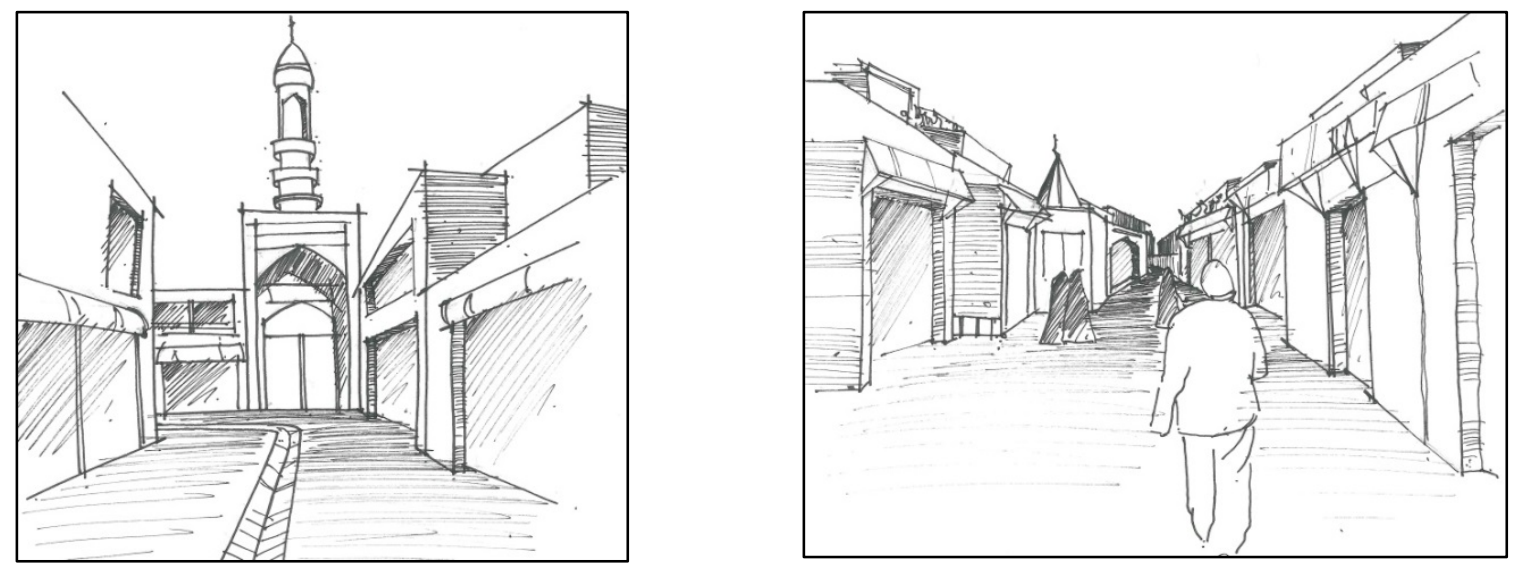

Figure 11: see the index element in the track (source: autho)

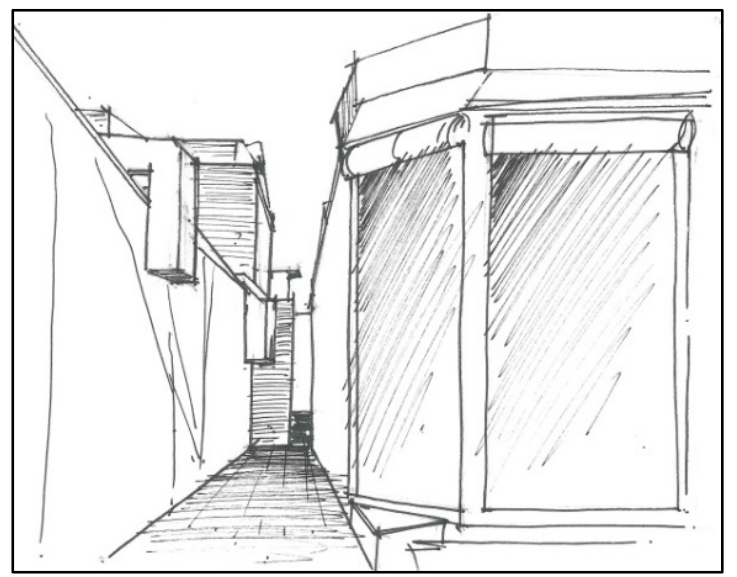

Figure 12: closeness of space in passing (Source: author)
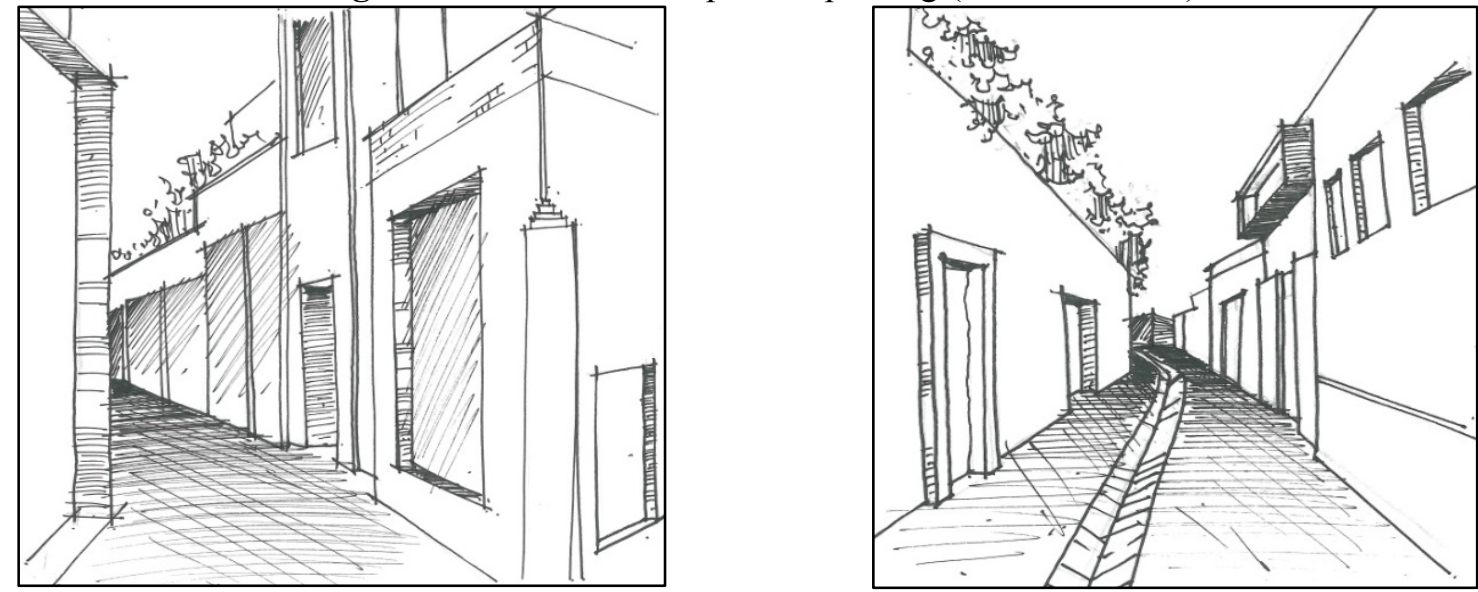

Figure 13: The passage of tortuous tissue (Source: author)

\section{MOVEMENT AND ACCESS SYSTEM}

The main passages Odlajan neighborhood lost their close relationship with adjacent neighborhoods with the widening of the street system of Reza Khan early this century. In the other hand,the street system and 
the widening of the range, causes the new structure created for the study area and it is taken as a whole and coherent set.

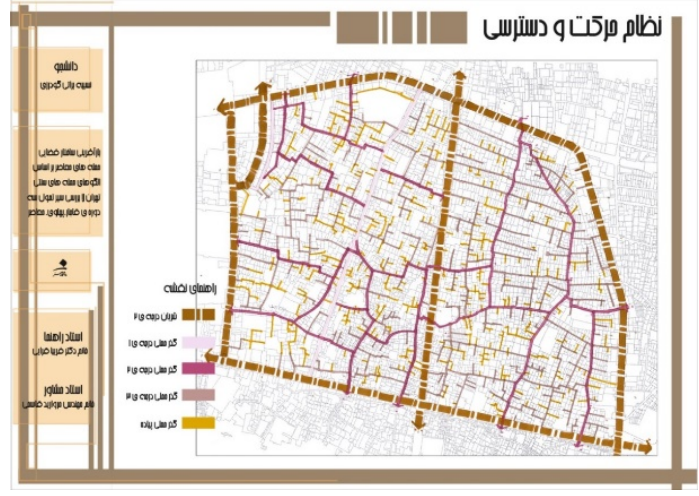

Figure 15: Hierarchy of access Odlajan neighborhood (Source: author)

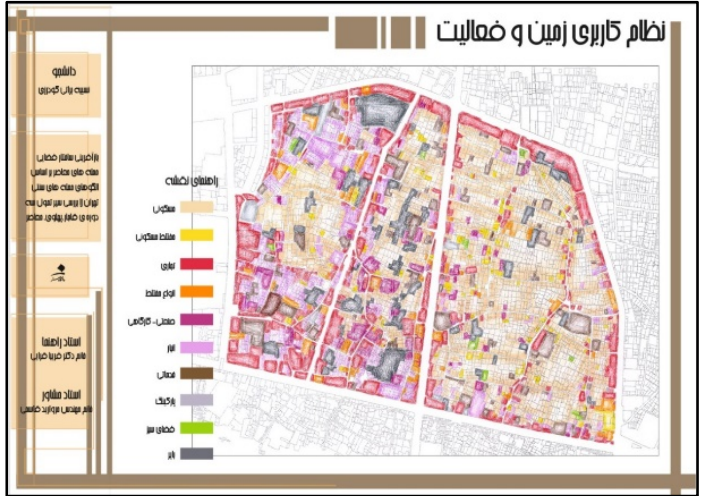

Figure 14: User in the neighborhood Odlajan (Source: author)

Because of the closeness of curvature of tracks and paths, as well as neighborhood and because of symptoms which are not very high, often symptoms are not visible from a distance. For example, during path the Dome of Emamzadeh Yahya can't be seen until closer to the brink. That is why signs have little role in determining their path.
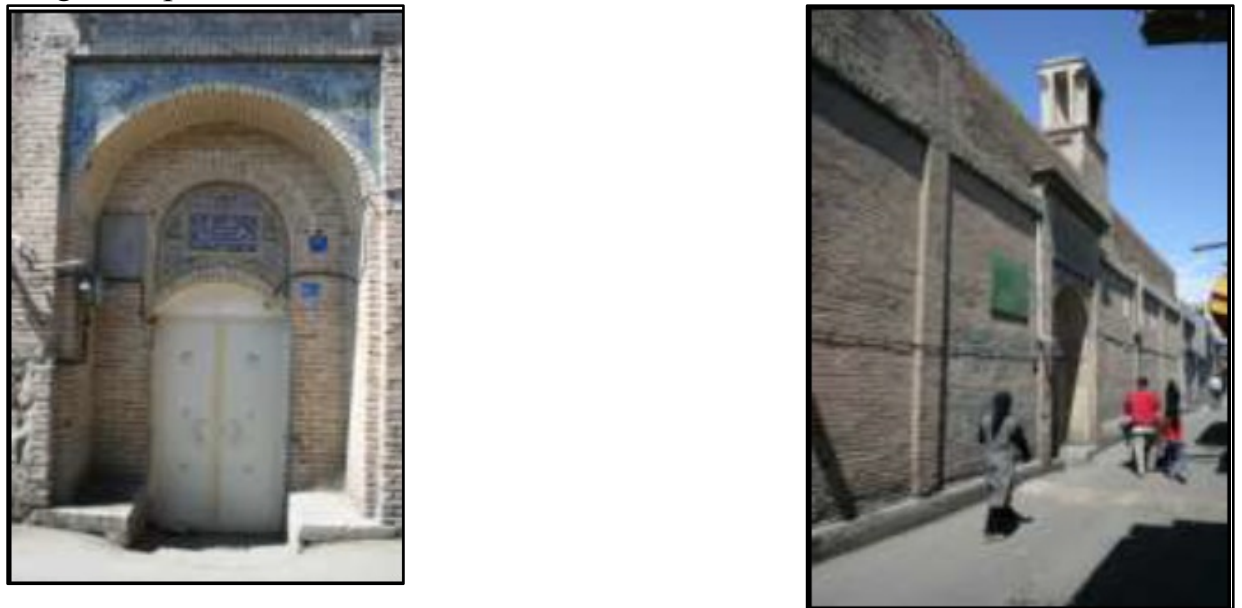

Figure 16: Mmarbashy mosque entrance with wind (Source: author)
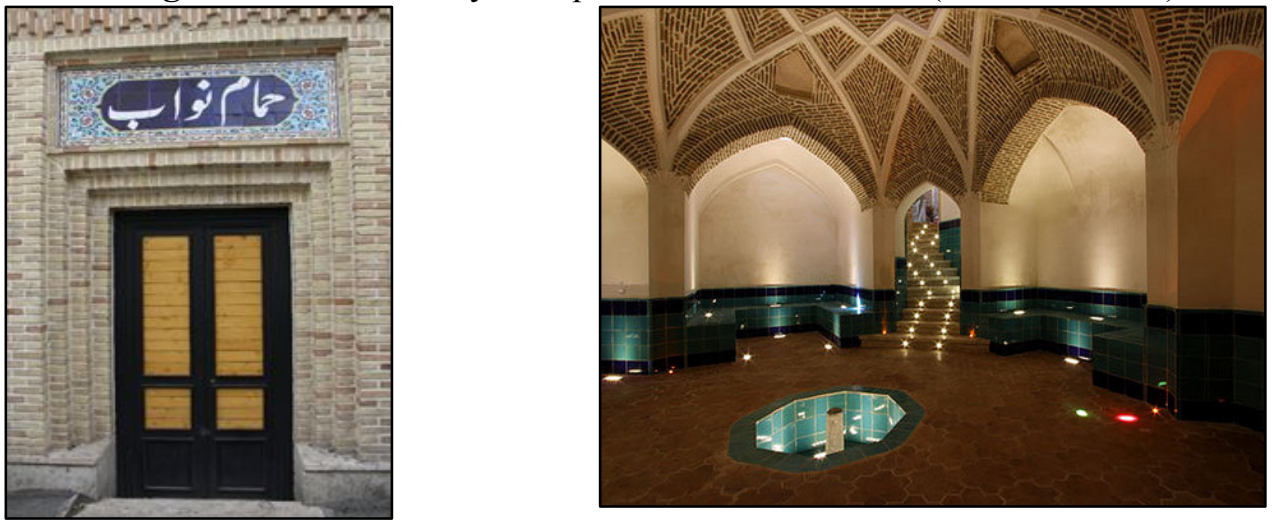

Figure 17: Nawab bathroom entrance (Source: author) 


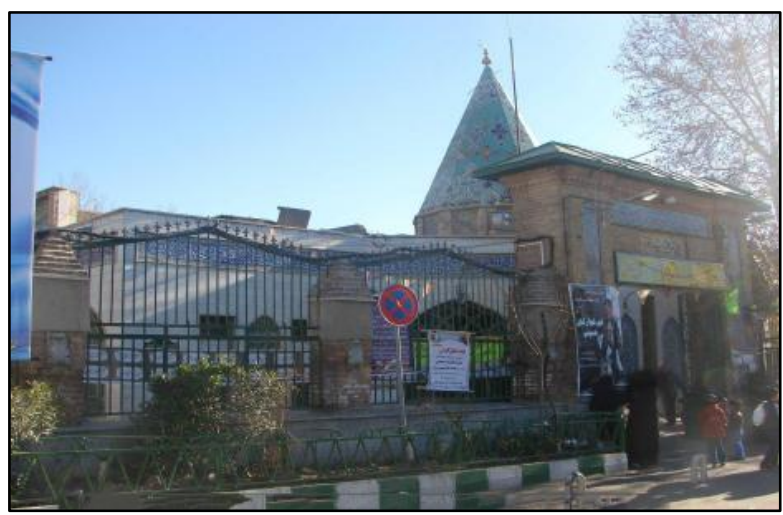

Figure 19: Yahya Zadeh (source: the author)

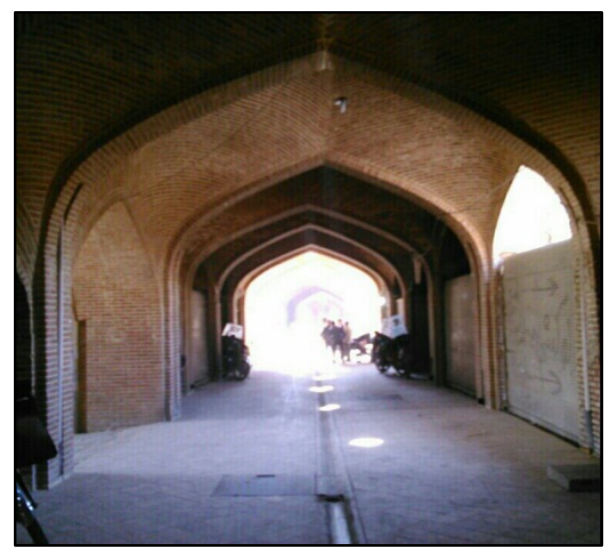

Figure 18: Feedback Odlajan (Source: author)

\section{SHAHID BAGHERI TOWN}

\section{UNDERSTANDING TERRITORY}

District 22 of municipalities, located in the North West of Tehran and with an area of about ten hectares (more than six thousand hectares of the service area), equivalent to twice the greatest area of Tehran, in other words make up one-seventh of the city area.

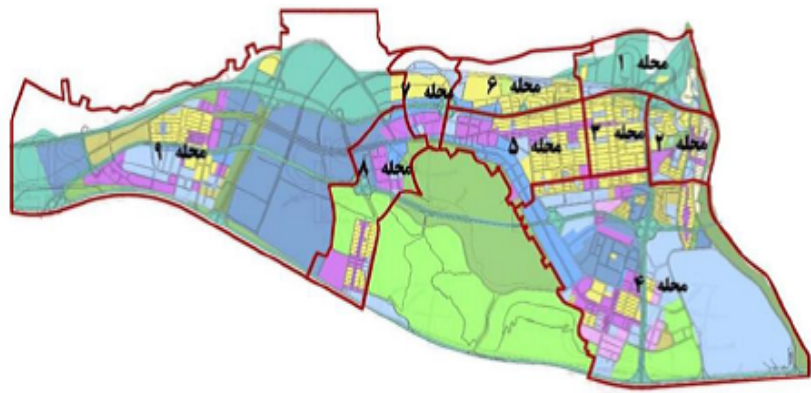

Figure 21: subdivisions in district 22 (Source: author)

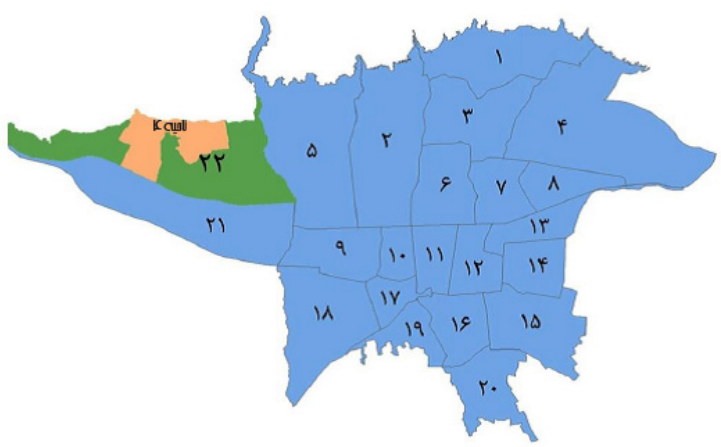

Figure 20: Location of the region (Source: author(

\section{RECOGNITION AND ANALYSIS OF THE STUDY AREA}

Area four is the most populous and widest area of the region. The area includes four stages, which Shahid Bagheri is one of them. This neighborhood is limited from the north to the Alborz Mountains, south to Highway Shahid Kharazi (Shahis Hemmat Gharb) and an artificial lake Persian Gulf Martyrs, from the East to Great Falls recreational complex in Tehran and from the West limits to entertainment complexes and commercial centers of Hezaroyek Shahr and residential area named "you and olives"

\section{THE PHYSICAL FORM}

Shahid Bagheri town includes of four- and six-storey buildings and green space between the blocks. In the internal area of neighborhoods, spaces are close enough because of the height of the buildings, but there are not close spaces around the area because of wide streets. The ratio of mass to space is less because of existence of green spaces between the blocks and predominance of space to mass can be seen in this town. 


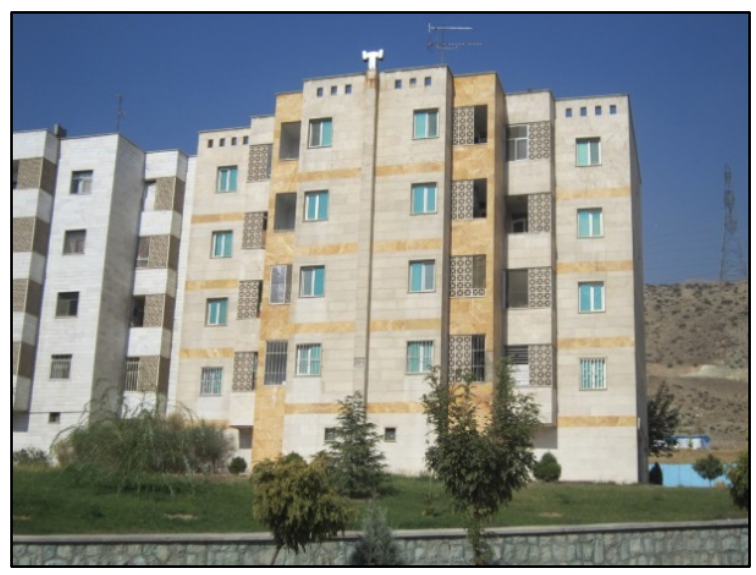

Figure 23: grille as identity

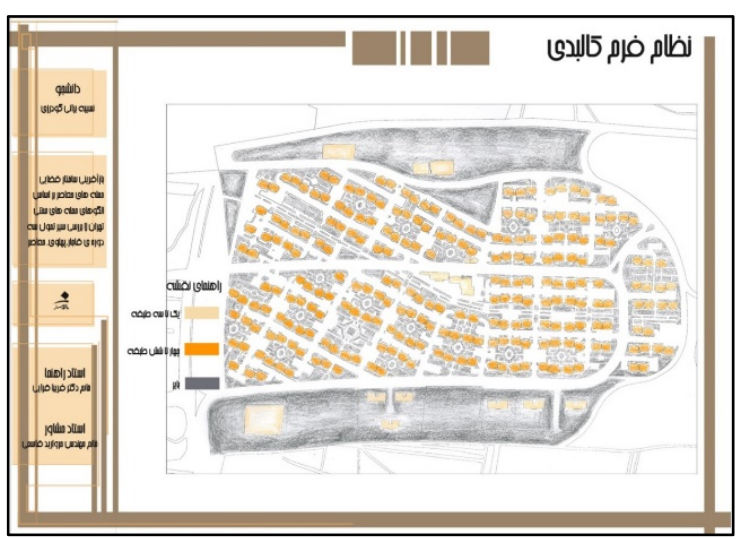

Figure 22: Construction classes Shahid Bagheri town

There are tall buildings makes it difficult to see the signs elements. But due to the placing of city on the high level and its appearance from the south, from the north see the shrine as a sign and foothils of the Alborz are its advantages.

City designed based on the car scale and not pay any attention to human scale. Shahid Bagheri town town skyline is almost uniform due to four to six-storey buildings, but again concave skyline and view to the city, there is no indication elements.

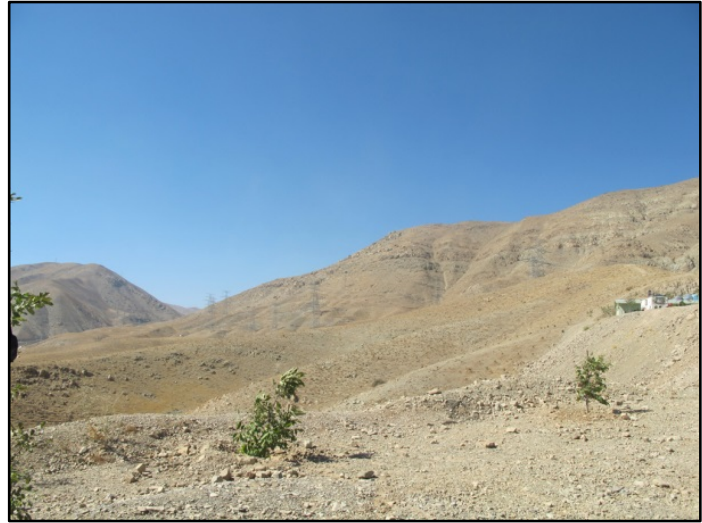

Figure 25: view from the inside out: see the Alborz

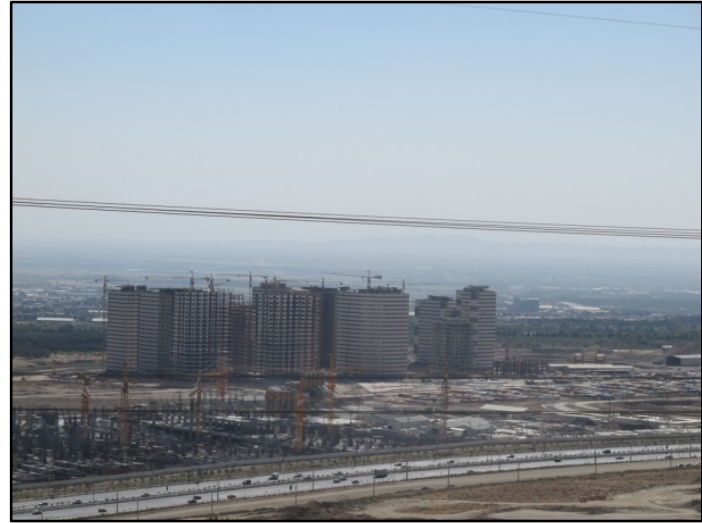

Figure 24: The view from the inside out: see the city

\section{RESULTS}

To recreate the spatial structure of the contemporary neighborhoods based on patterns of traditional neighborhoods of Tehran, after extracting patterns from traditional ones in terms of form, function and meaning, determined according to the needs of today needs and changes of these patterns in modern times and comparing these two periods.

Some of these patterns remain constant, others on the effect of urbanization and modernity have changed very quickly and some of them are gone. Then the patterns determined to recreate today, according to the needs. Finally, attempts are done to provide the principles and criteria and proposals for the better neighborhoods. 
ANALYSIS OF THE RESULTS OF THE PHYSICAL FORM AND URBAN LANDSCAPE

Based on the principles and patterns extracted in the theoretical foundations of traditional neighborhoods and the needs of today's society and recreating the patterns and principles, principles and standards proposed in the form of three factors of form (the physical form, the urban landscape) as follows:

Table 2: Principles and proposed standards in the design of modern neighborhoods on the principles and patterns of traditional ones

(The physical form)

\begin{tabular}{|c|c|c|}
\hline Criterion & Principles & Form \\
\hline $\begin{array}{l}\text { - semi-private spaces between the private and } \\
\text { public } \\
-\quad \text { - the importance of reducing the degree of space } \\
\text { and its surrounding elements and define them with the } \\
\text { degree of importance of space } \\
\text { - introversion and simplicity in buildings such as } \\
\text { housing, school, etc. } \\
\text { - respect the confidentiality of the hierarchy of } \\
\text { spaces using elements such as tracks and natural elements } \\
\text { such as trees and devious. }\end{array}$ & $\begin{array}{l}\text { The principle of } \\
\text { hierarchy (privacy } \\
\text { and territory) }\end{array}$ & \multirow{5}{*}{$\begin{array}{l}\text { The } \\
\text { physical } \\
\text { form }\end{array}$} \\
\hline $\begin{array}{l}\text { - create a forecourt and an important arena for } \\
\text { public uses to transition from public to private space } \\
-\quad-\text { pause and gather in front of the user and } \\
\text { embedded spaces }\end{array}$ & $\begin{array}{l}\text { Article realm and } \\
\text { the realm of }\end{array}$ & \\
\hline $\begin{array}{l}\text { - create human scale in space as the most important } \\
\text { pillar of space } \\
-\quad \text { create closeness with the continuity of the space } \\
\text { enclosed body or natural elements } \\
-\quad \text { the proportion of height to width in space to create } \\
\text { a sense of closeness } \\
-\quad \text { track and field space is determined by continuous } \\
\text { body }\end{array}$ & The closeness & \\
\hline $\begin{array}{l}\text { - the use of local materials and coordination to } \\
\text { continue with the form and context } \\
-\quad \text { - the odd views or recurring stalls or element of } \\
\text { continuity walls } \\
-\quad \text { allowed the formation of neighborhoods in } \\
\text { continuity with previous tissue for organic } \\
\text { - Create constancy of bodies in space and avoid } \\
\text { gaps and missing areas in the context of }\end{array}$ & $\begin{array}{c}\text { The principle of } \\
\text { continuity }\end{array}$ & \\
\hline 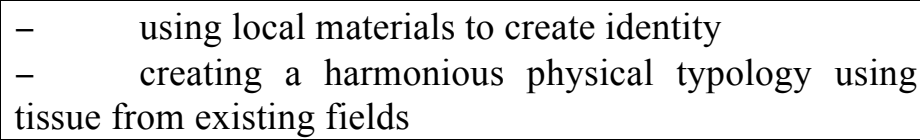 & $\begin{array}{l}\text { Field-oriented } \\
\text { principles }\end{array}$ & \\
\hline
\end{tabular}




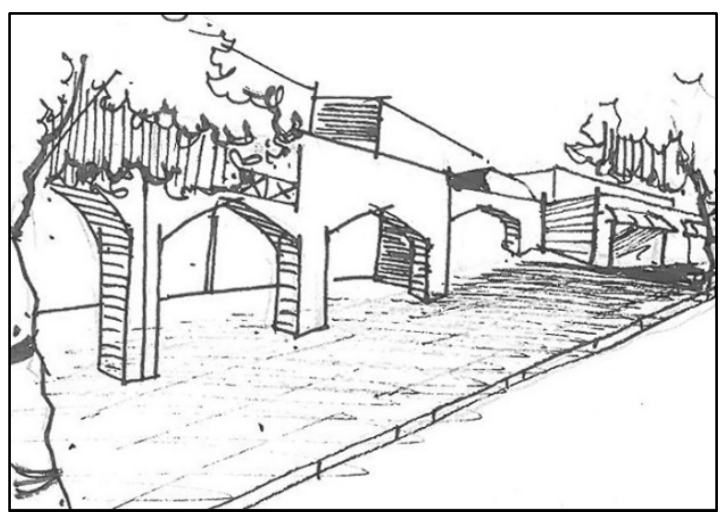

Figure 27: Use of local materials

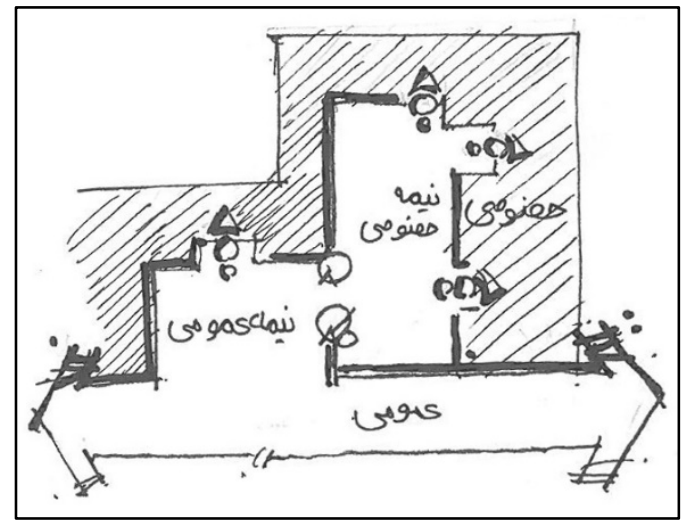

Figure 29: Track and field space is determined by continuous body

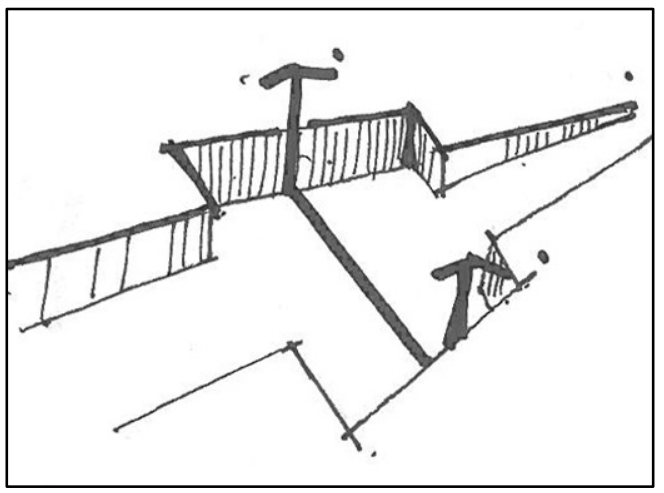

Figure 31: observe confidentiality with the hierarchy of spacel

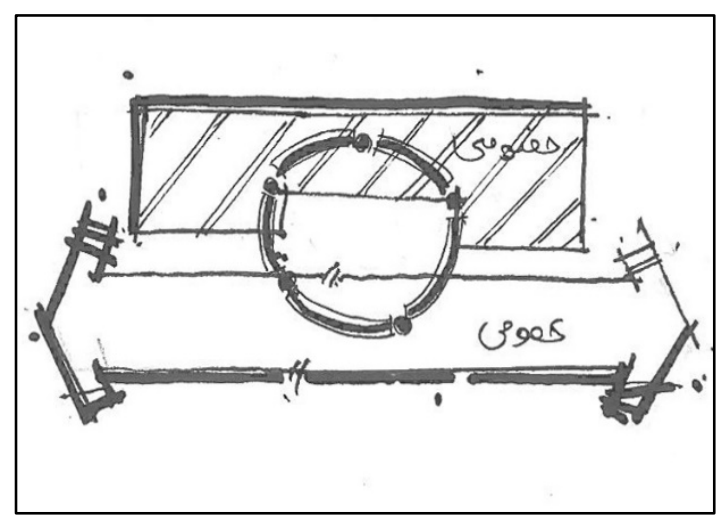

Figure 26: Create forecourt and areas for public use

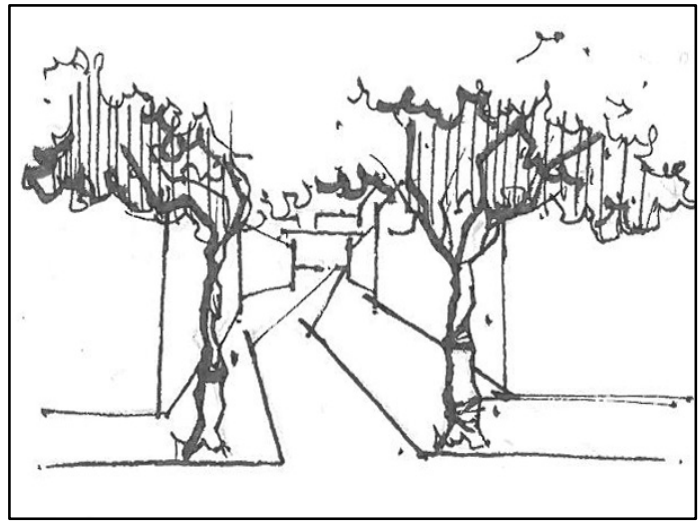

Figure 28: observe confidentiality with the hierarchy of spacel

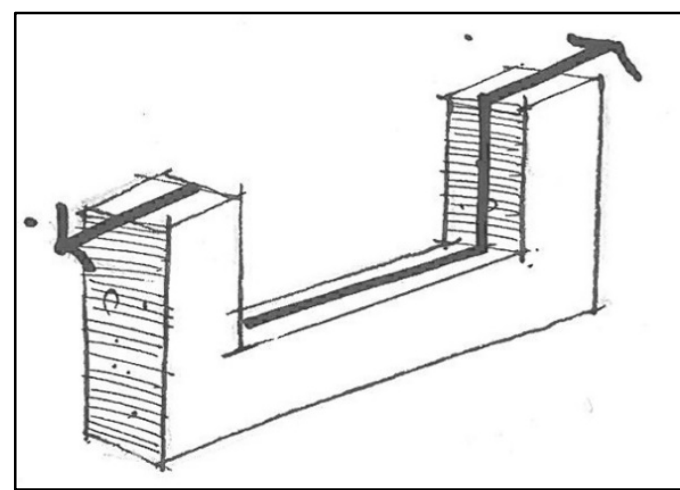

Figure 30: Proportion of height to width in space 


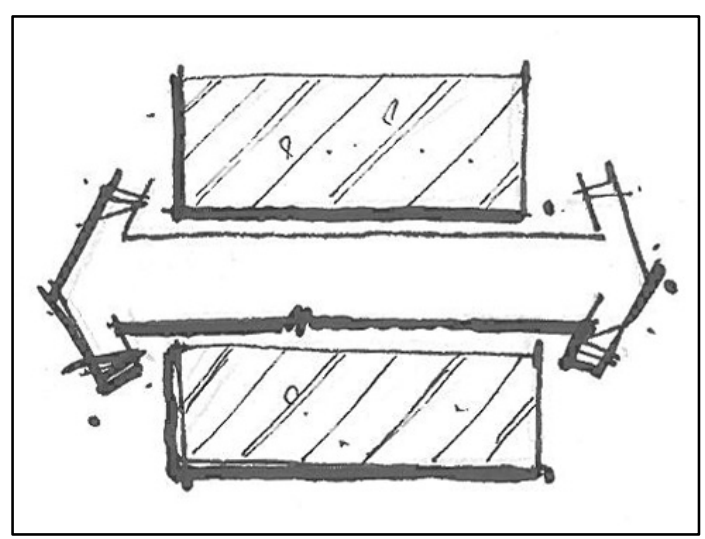

Figure 33: Continuation of the body in space

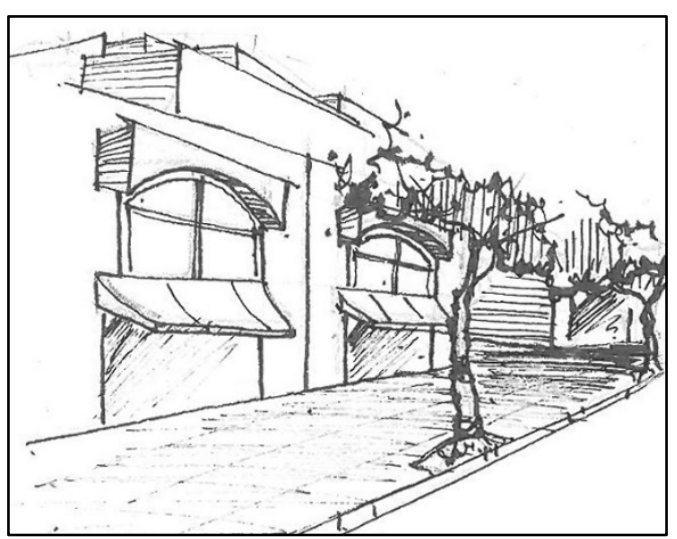

Figure 32: Use of recurring element in the chamber

Table 3: Principles and proposed standards in the design of modern neighborhoods on the principles and patterns of traditional ones

(The urban landscape)

\begin{tabular}{|c|c|c|}
\hline Criterion & Principles & Form \\
\hline $\begin{array}{l}\text { - } \quad \text { create a hierarchy Elevation and urban horizon } \\
\text { convex to improve readability } \\
-\quad \text { to see the signs and visual indicator with a lower } \\
\text { hierarchical elements to a height of up elements }\end{array}$ & $\begin{array}{c}\text { The principle of } \\
\text { hierarchy }\end{array}$ & \multirow{5}{*}{$\begin{array}{l}\text { The urban } \\
\text { landscape }\end{array}$} \\
\hline $\begin{array}{ll}- & \text { create an indirect route to various see } \\
- & \text { use of light and shadow and opening the path } \\
- & \text { Add variety to the space enclosed by a margin of } \\
\text { closeness and height of the space body }\end{array}$ & $\begin{array}{c}\text { The contrast of } \\
\text { Space }\end{array}$ & \\
\hline $\begin{array}{l}\text { Coordinate and streamline the body and highlight } \\
\text { important elements to disrupt this Article } \\
-\quad \text { Manifesting itself for no reason and index the core } \\
\text { elements of buildings such as mosques and read the local } \\
\text { neighborhood } \\
-\quad \text { the use of local materials and coordinating bodies }\end{array}$ & $\begin{array}{l}\text { The principle of } \\
\text { simplicity }\end{array}$ & \\
\hline 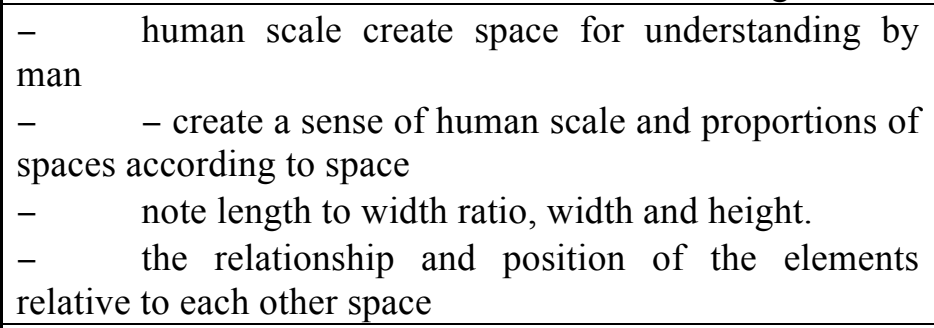 & $\begin{array}{c}\text { The scale and } \\
\text { proportion }\end{array}$ & \\
\hline $\begin{array}{l}\text { - creating a continuous and non-interrupted sky and } \\
\text { empty it once } \\
-\quad \text { continuation of existing glazed areas and the gap } \\
\text { with changes in successive shots and materials } \\
-\quad \text { the use of repetitive elements in order to maintain } \\
\text { the continuity of facades and walls } \\
-\quad \text { harmonious relationship in terms of the pillars and } \\
\text { other structures in the neighborhood Views }\end{array}$ & $\begin{array}{l}\text { Principle of } \\
\text { continuity }\end{array}$ & \\
\hline
\end{tabular}




\begin{tabular}{||l|c|c|}
$-\begin{array}{l}- \\
\text { deal with it }\end{array}-\quad \begin{array}{c}\text { conflict with important fields when creating a } \\
\text { visual indicator elements }\end{array}$ & $\begin{array}{c}\text { Field-oriented } \\
\text { principles }\end{array}$ \\
\hline- & $\begin{array}{l}\text { continuous wall design but with varied forms } \\
-\end{array} \quad \begin{array}{l}\text { the use of natural elements in the design walls } \\
-\end{array} \quad \begin{array}{c}\text { diversity of vision in contrast with the space } \\
\text { diversity }\end{array}$ \\
\hline
\end{tabular}

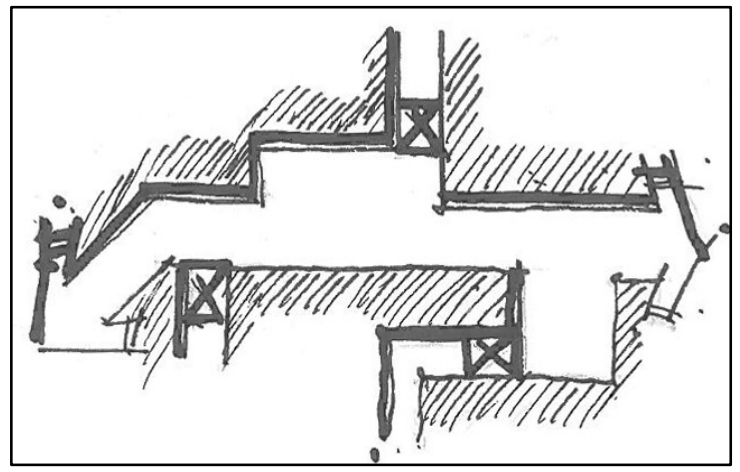

Figure 35: The use of light and shadow and opening

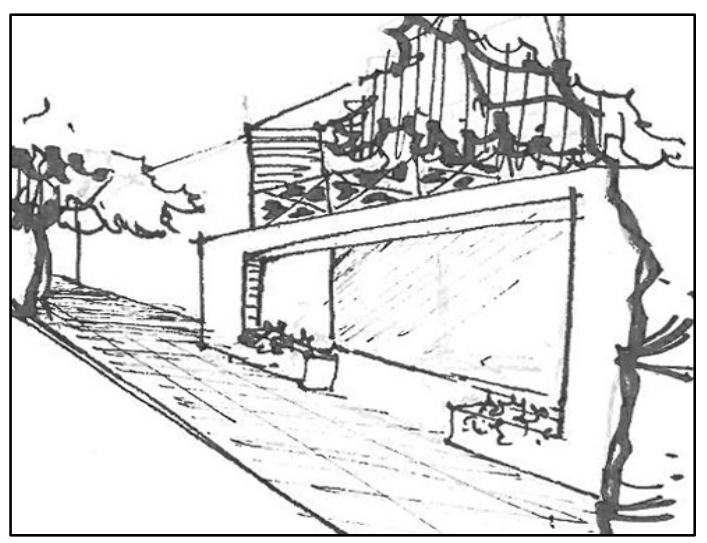

Figure 37: Use natural elements (plants) in the main chamber design!

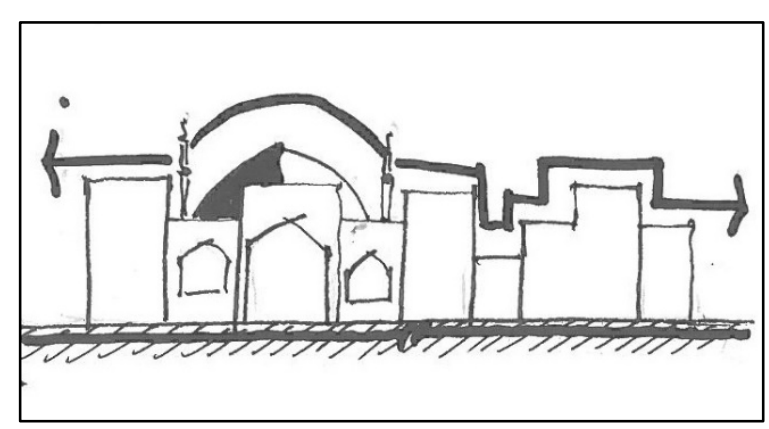

Figure 39: Creating a sustainable sky

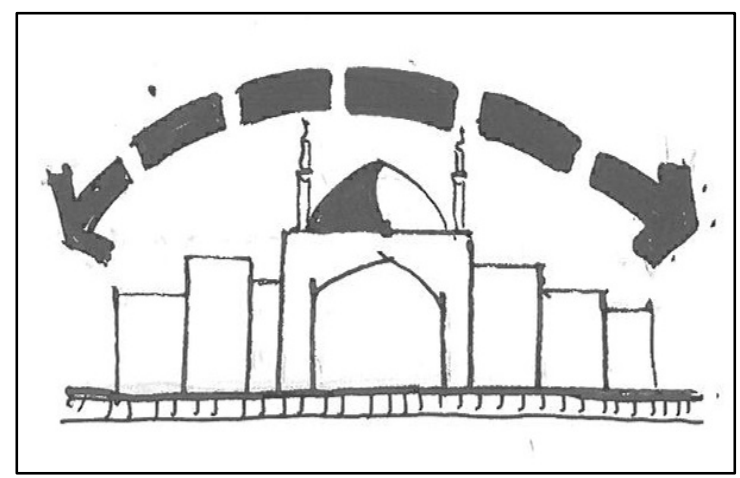

Figure 34: Hierarchy of Elevation and urban horizon convex

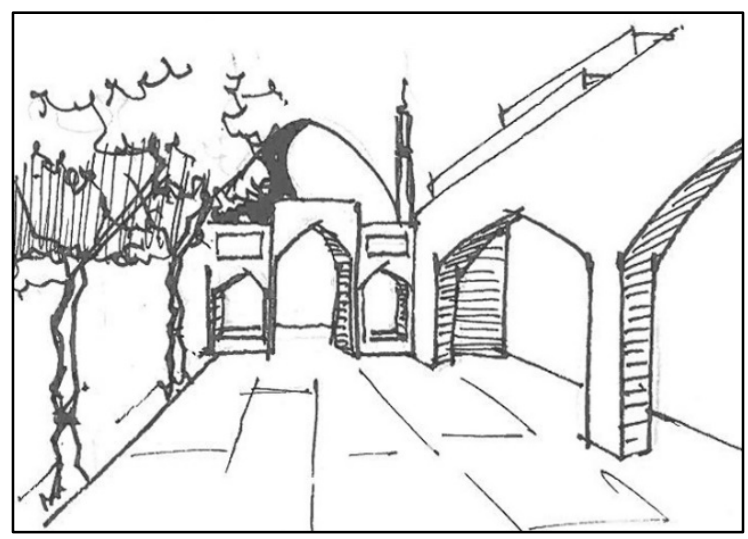

Figure 36: Lack of monuments, manifesting itself without any reason and the index of the core neighborhood elements

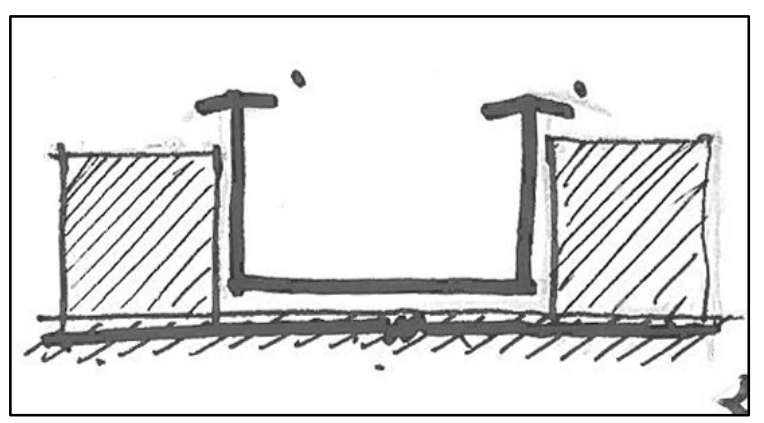

Figure 38: The ratio of length to width, height, width 


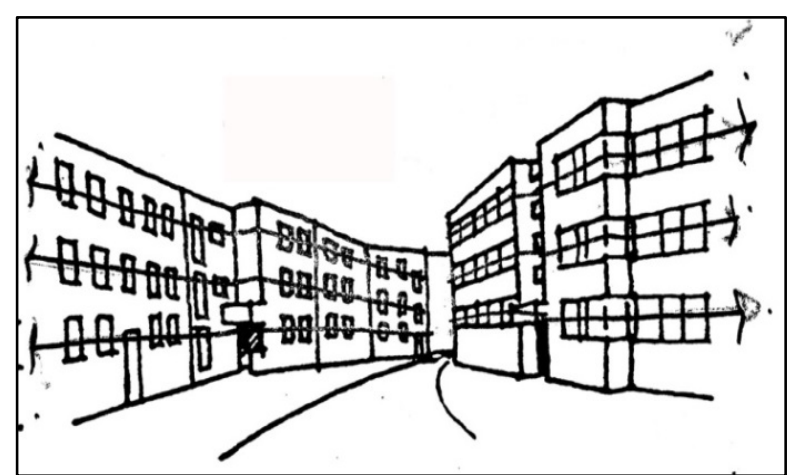

Figure 41: harmonious relationship glazed elements and components of Views

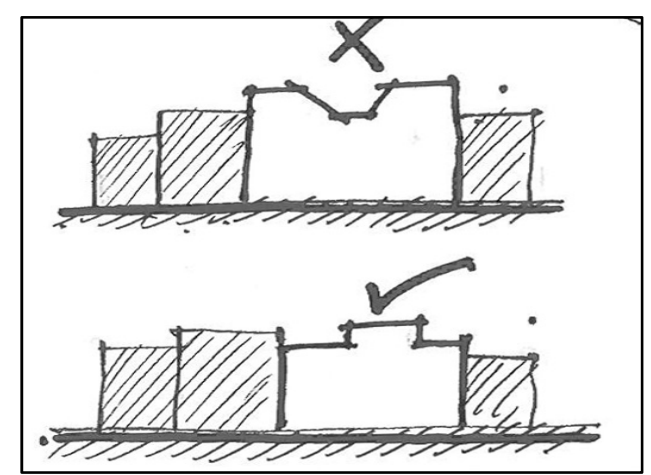

Figure 40: Creating harmony with the background views

\section{CONCLUSION}

In modern times, the popularity of new urbanism, urban areas with disregard for the history and nature of the newly founded traditional ones, overcoming spiritual and material factors on the human machine control, conceptually quite bizarre, meaningless and have found used only in the level of a urban division unit. However, given that the areas, once the crystallization of social and economic dynamics of urban life and are now due to lack of contemporary body and existing activities, with many problems have faced, the need to reinvent the concept of neighborhood, is considered essential. For this reason, the use of traditional patterns as a symbol of urban areas on the one hand and the needs of indigenous identity and solidarity on the other hand can bring the past into the present-day neighborhoods and at the same time meet the needs of the current residents. Overall, the study seeks to recreate the old values of contemporary and urban neighborhoods in response to the lack of efficiency of new urban forms and functions, followed by lack of understanding of the applicability of these two together under the banner of spatial structure to finally be able to revive targets the physical structure of neighborhoods, strengthen identity and looking for meaning and understanding of the neighborhoods and attract residents achieve the regeneration of this neighborhood will not be achieved spatial structure.

To collect the required information and research interests, Odlajan neighborhood Qajar era and the contemporary period Shahid Bagheri settlements in the region 22 is selected. The resulting patterns based on theory and literature, is employed and to recreate these patterns in order to present them for use in the design of modern neighborhoods. In this study, we tried to extract traditional urban design in contemporary Qajar and its spatial patterns of Tehran by analysis of them.

\section{REFERENCES}

Ayini,M.- Ardestani,Z. (2009)-"Pyramid endogenous development plans for urban regeneration and public participation criteria"- Journal of city identity-No.5- Pages 5-47

Batey, P. (2000), Urban Regeneration in Britain: Progress, Principles and Prospects, International Symposium on Regeneration of City Down Town.

Habibi, S.M. (2008)-“Tehran; Capital city of Qajar”- Journal of Conversation-No.3.

Habibi, S.M. (2002)-“ Urban restoration”-Tehran university publisher.

Habibi, S.M. (1996)-"From town to city- Historical analysis of the concept of the city and its physical appearance"-Tehran university publisher.

Mahmoudian, A. - (2005)-“ Look at the Tehran since the beginning"- GitaShenasi publisher.

Moazzami,M. (2011)-“Treatment of space in the architecture education"- Journal of Fine Arts Architecture and Urbanism No. 48- Pages: 57-68.

Najmi,N. (1989)- “Tehran in Nasseri Era"-Attar Publisher-Third Publish. 
Rahnamayi,M.T. - Shah Hoseini,P. (2004)-“ Iran's urban planning process”-SAMT publisher.

Shamayi,A. (2010)- The role of traditional urban patterns in modern city of Yazd. Studies in Islamic \& Iranian city Quarterly-No.1-Page93-105

Shiye,E. (1999)- "Cities in Iran"- Science and Technology University Publisher.

Soltanzadeh,H. (2013)-“ Urban spaces in historical context”- Cultural Research publisher.

Soltanzadeh,H. (2011)-“ Brief history of urbanism in Iran(From ancient times to 1976)”- Chahartaq publisher.

Tahsildar,M.- Farnaq,H. (1992)-“Criterion to determine urban neighborhood”- MA thesis of urbanismFine Arts Faculty of Tehran University

Tavassoli,M. (2009)-“Urban design; Renew the city”-Khane Chapotarh publisher

Tavassoli,M. (1997)-“ Principles and design methods”- Architecture and Urbanism research center publisher 